\title{
Adsorption of Silver Nanoparticles from Aqueous Solution by Multiwalled Carbon Nanotubes
}

\author{
Dalia M. A. Hassan, Mohamed R. F. Farghali* \\ Department of Animal Hygiene, Faculty of Veterinary Medicine, Assiut University, Assiut, Egypt \\ Email: *mohamed.fahmey@vet.au.edu.eg, ${ }^{\star}$ m_ramadan016@yahoo.com
}

How to cite this paper: Hassan, D.M.A. and Farghali, M.R.F. (2017) Adsorption of Silver Nanoparticles from Aqueous Solution by Multiwalled Carbon Nanotubes. Advances in Nanoparticles, 6, 22-32. https://doi.org/10.4236/anp.2017.62003

Received: February 10, 2017

Accepted: March 25, 2017

Published: March 28, 2017

Copyright (๑) 2017 by authors and Scientific Research Publishing Inc. This work is licensed under the Creative Commons Attribution International License (CC BY 4.0).

http://creativecommons.org/licenses/by/4.0/

(c) (i) Open Access

\begin{abstract}
Silver nanoparticles (AgNPs) are becoming an emerging pollutant of the environment. In this study, the efficacy of Multiwalled carbon nanotubes (MWCNTS) to remove AgNPs from aqueous solution at a concentration of 250 and $500 \mathrm{mg} / 100 \mathrm{ml}$ MWCNTS was investigated. The results showed that the adsorption of AgNPs by 250 and $500 \mathrm{mg} / 100 \mathrm{ml}$ MWCNTS after a contact time of $10 \mathrm{~min}$., $30 \mathrm{~min}$., $60 \mathrm{~min}$., $120 \mathrm{~min}$. and $240 \mathrm{~min}$ was $33.95 \%, 34.36 \%$, $40.32 \%, 45.33 \%, 58.53 \%$ and $57.29 \%, 61.27 \%, 64.89 \%, 87.21 \%, 88.58 \%$, respectively. The statistical analysis of data showed that, after adding 250 and 500 $\mathrm{mg} / 100 \mathrm{ml}$ MWCNTS, the total residues of AgNPs were significantly reduced in all MWCNTS exposed samples when compared to the control groups $(\mathrm{P}<$ 0.05). Moreover, at the two used concentrations, there were significant differences between $240 \mathrm{~min}$. and all other contact times. The result concluded that the removal percent of AgNPs from aqueous solution was increased with the increase in contact time and concentrations of MWCNTS. Additionally, MWCNTS are expected to be potential adsorbent in the future due to their high removal capacity of nano-sized silver.
\end{abstract}

\section{Keywords}

Silver Nanoparticles, Multiwalled Carbon Nanotubes, Adsorption, Water Treatment

\section{Introduction}

Water scarcity in many regions of the world is exerting a great pressure on establishing more advanced technology to provide good quality water for human, animals and other uses. Recently, nanomaterials (materials less than $100 \mathrm{~nm}$ in at least one dimension) have attracted more attention due to the increase of their production, their wide applications [1], their unique physicochemical properties, 
and their potential hazards to the natural environment [2]. Nowadays, nanoparticles are becoming more common emerging contaminants of water [3]. As one of the most promising metals nanoparticles of various antimicrobial and antiviral properties, silver nanoparticles (AgNPs) have been widely used in the daily life such as biomedical devices, air and water filters, packaging of food, cosmetics, clothing/textiles, electronic appliances, and cleaning agent [2] [4] [5] [6]. In a 2013 survey, from 622 companies in 32 countries, there are 1814 consumer nano products, and silver $(\mathrm{Ag})$ is the most frequently used nanomaterial (435 products, or 24\%) [7]. According to Blaser et al. [8], silver (Ag) residues from Asia, Europe, and North America reached 190 - 410 tonnes/year. Furthermore, between $11.5 \%$ to $31.7 \%$ of Ag residues passed through Waste Water Treatment Plants and were found in receiving natural water [9] [10].

The widespread uses of AgNPs can result in their leaching into natural water, where AgNPs can be toxic to bacteria [11], invertebrates [12], algae [13], and plants [14]. The behavior and toxicity of AgNPs vary according to sediment characteristics and water chemistry [15], while, in natural water, AgNPs could be transformed through oxidation, sulfidation, reduction, dissolution, aggregation, and adsorption [16]. These transformations have an influence on the mobility, persistence, and bioavailability of the AgNPs [16].

In order to assess the emerging threats from AgNPs, one should take into account their toxicity degree and exposure route [17]. After oral administration of silver in mammals, it can distribute to all organs. The following dose-dependent toxicity findings have been reported in animals: death, hypoactivity, weight loss, altered liver enzymes, altered neurotransmitter levels, enlarged hearts and immunological effects [18], in addition to argyria of the skin.

AgNPs consider a new class of emerging drinking water pollutants, and there is pressing need to remove them during drinking water treatment. Carbon nanotubes (CNTs) have drawn great attention since they were discovered in 1991 [19]. Carbon nanotubes (CNTs) include multiwalled carbon nanotubes (MWCNTs) and single-walled carbon nanotubes (SWCNTs) depending on the number of layers comprising them. MWCNTs have cylindrical shape consisting of a multiple layers of graphene sheets rolled up in a tube-like structure [20]. CNTs have a great potential due to their unique properties such as remarkable chemical, mechanical stabilities, nano sizes, and their strong adsorption properties [21] that are mainly attributed to their pore structure and the existence of a wide surface functional group [25] [26]. MWCNTs have been used as adsorbent for many types of pollutants such as many heavy metals [22], pesticides [23], and sulfonamides [24].

Although there are numerous laboratory tests and experimental studies carried out in recent years concerning the adsorption of several contaminants by using MWCNTs, there is still a significant gap in the literature to investigate the adsorption capabilities of MWCNTS for the removal of AgNPs. For this reason, this work has been conducted as a novel study specifically aimed to determine the effects of different concentration of MWCNTs and different contact time on 
the removal of AgNPs from aqueous solution.

\section{Material and Methods}

\subsection{Synthesis of AgNPs Stock Solution}

One typical step protocol was used to synthesize AgNPs according to Vigneshwaran et al. [27] where; $1.0 \mathrm{~g}$ of soluble starch was added to $100 \mathrm{~mL}$ of distilled water and heated till complete dissolution. Then, $1 \mathrm{~mL}$ of a $100 \mathrm{mM}$ aq solution of silver nitrate $\left(\mathrm{AgNO}_{3}\right)$ crystal, (GAMMA laboratory chemicals, with minimum assay of 99.0\%) was added and mixed well. This mixture was transferred into dark glass bottle and kept in an autoclave at $121^{\circ} \mathrm{C}$ for $5 \mathrm{~min}$. The use of soluble starch for the production of AgNPs is a simple and fast method and offers several benefits of compatibility for biomedical applications. After preparation of AgNPs, the stock solution was kept in dark bottle away from direct sunlight at room temperature; the concentration and size of the particles were measured before it's used in experiments.

\subsection{Characterization of AgNPs}

The size of AgNPs was measured by Transmission Electron Microscopy (TEM) Model JEOL-JEM-100CX II, in Electron Microscopy Unit, Assiut University, Egypt. The total concentration of AgNPs stock was analyzed by Atomic Absorption spectrophotometer (Graphite Furnace) Model 210VGP in heavy metals analysis lab, Faculty of Science, Assiut University, Egypt.

\subsection{Adsorbent Properties}

Multi-walled carbon nanotubes (MWCNTs) were purchased from Nano Tech Company (Al Giza, Egypt), and used as the adsorbent materials in the present study. According to the manufacture report sheet, the MWCNTs have been prepared by arc-discharge in solution. The arc discharge technique involves the use of two graphite electrodes of high purity as the anode and the cathode. The electrodes were vaporized by the passage of a 100A DC current through two graphites separated in 400 mbar of Helium atmosphere. After arc discharging for a period of time, a carbon rod is built up at the cathode. Size, diameters and shapes of MWCNTs were measured by the Transmission Electron Microscopy (HR-TEM) model JOEL JEM-2100 operating at $200 \mathrm{kV}$ equipped with Gatan digital camera Erlangshen ES500.

According to data provided by the manufacturer, MWCNTs were Tubular-like shape, their length was $>660 \mathrm{~nm}$ and the diameters were $20 \pm 5 \mathrm{~nm}$ (Figure 1).

\subsection{Adsorption Experiments}

\subsubsection{Preparation of Test Solutions (Samples)}

Preparation of test solutions was carried out in 2 conical flasks of $1 \mathrm{~L}$ capacity, each flask containing $240 \mathrm{ml}$ of distilled water with neutral $\mathrm{pH}$. In the next step, 10 $\mathrm{ml}$ of silver nanoparticles from a stock solution were added into each conical flask. 


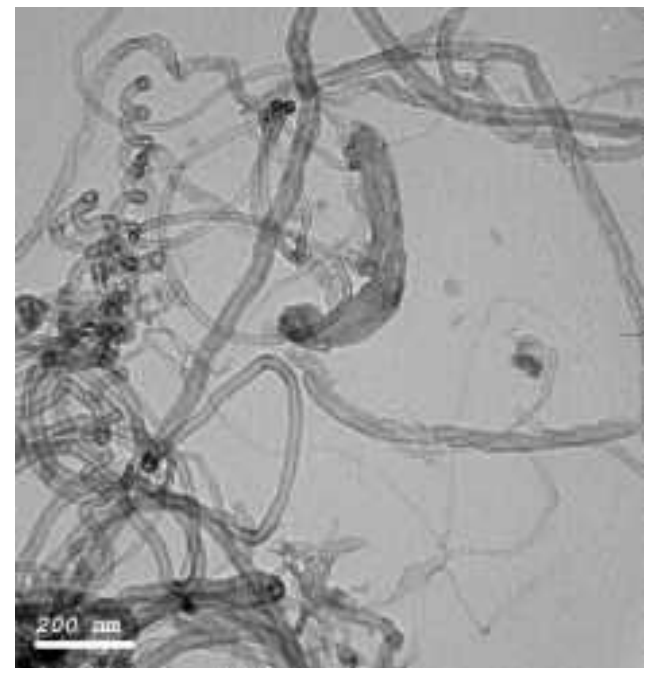

Figure 1. TEM micrographs showed that, the as-prepared CNT has multiwall structure and size of $20 \pm 5 \mathrm{~nm}$.

\subsubsection{Effect of Adsorbent Amount and Contact Time}

In this study, the amount of MWCNTS specified for each sample was weighed and added to test solutions to obtain a final concentration of 250 and $500 \mathrm{mg} /$ $100 \mathrm{ml}$ MWCNTS. After that, the conical flasks containing test solution and adsorbents were shaken at $150 \mathrm{rpm}$ in a thermostatic horizontal shaker set at $30^{\circ} \mathrm{C}$ for several specified contact times namely; $10 \mathrm{~min}$., $30 \mathrm{~min}$., $60 \mathrm{~min} ., 120 \mathrm{~min}$. and $240 \mathrm{~min}$. The experiments were carried in triplicate.

\subsubsection{Analysis and Detection of AgNPs}

At the end of each specified contact time, the conical flasks were removed from the shaker and the solution was passed through a filter paper (Whatman No. 43 and $15 \mathrm{~cm}$ diameter) to separate the MWCNTs from the solution, the filtrate was labelled and transferred to Heavy metals analysis lab. at Faculty of Science, Assiut University to analyze the residual amount of total silver by using Atomic absorption spectrophotometer (Model No: 210VGP).

\subsubsection{Evaluation of Adsorption Efficacy of MWCNTs}

The efficiency of MWCNTs to adsorb AgNPs was calculated by comparing the amount of AgNPs before (The control), and after adding the MWCNTs at specified contact time to determine if there were significant differences between them. Percent efficacy was calculated with the following equation:

$$
P=\left(C_{0}-C\right) / C_{0} \times 100
$$

where $P$ is the percent of adsorption efficacy, $C_{0}$ is the initial amount of AgNPs (control); $C$ is the amount of AgNPs after a certain contact time with MWCNTS.

\subsection{Statistical Analysis of Data}

Statistical analysis of data was carried by using SPSS software version 17.1. The data was subjected to analyses of variance using the ANOVA procedure of SPSS software. The results were presented as mean and standard errors for each varia- 
ble. Differences between mean values were tested using Duncan's multiple range test. $\mathrm{P}$-value consider statistically significant when $\mathrm{P}<0.05$.

\section{Results and Discussion}

\subsection{Characterization of Synthesized AgNPs}

After autoclaving, the resulting solution was yellow in color indicating the formation of AgNPs. The size of AgNPs was ranged from 3.76 to 10.9; they have spherical shapes as shown in Figure 2. The concentration of the stock solution of AgNPs was $132 \mathrm{mg} / \mathrm{L}$. Prepared Nanoparticles were stable in solution over a period of 3 months at room temperature $\left(25^{\circ} \mathrm{C}\right)$ and show no signs of aggregation.

\subsection{Effect of MWCNTS on Adsorption of AgNPs}

The increasing and wide application of silver nanoparticles (AgNPs) has resulted in their appearance in water specially, wastewater. In consideration of their potential toxicity and environmental impacts, it is urgently to find effective technology for their removal from water. In this study, the AgNPs contaminated Distilled Water (DW) with $132 \mathrm{mg} / \mathrm{l}$ was treated by using two different MWCNTS doses $(250$ and $500 \mathrm{mg} / 100 \mathrm{ml})$. The results showed that the mean values of AgNPs after adding $250 \mathrm{mg} / 100 \mathrm{ml}$ and $500 \mathrm{mg} / 100 \mathrm{ml} \mathrm{MWCNTS}$ were

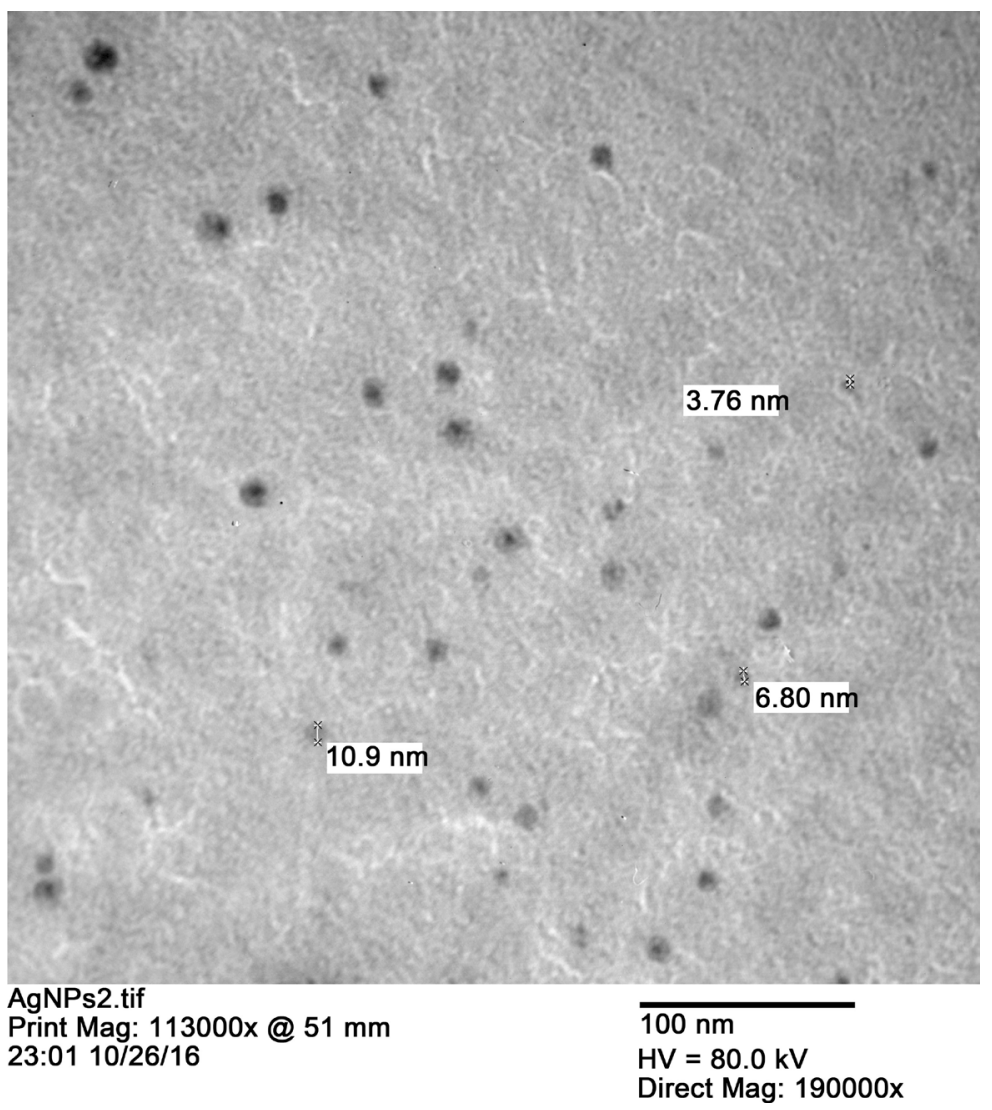

Figure 2. TEM image of AgNPs showing spherical shaped nanoparticles with size particles ranged from 3.76 to 10.9 . 
$(17.18 \pm 0.41,17.07 \pm 0.67,15.52 \pm 0.55,14.22 \pm 0.32,10.78 \pm 0.07$, and $26.00 \pm$ $3.04)$, and $(11.11 \pm 0.35,10.07 \pm 0.25,9.13 \pm 0.55,3.33 \pm 0.31,2.97 \pm 0.02$ and $26.00 \pm 3.038$ ) at contact time of $10 \mathrm{~min} ., 30 \mathrm{~min} ., 60 \mathrm{~min} ., 120 \mathrm{~min}$. and 240 min and control (before adding MWCNTS) samples, respectively Table 1 and Figure 3.

The statistical analysis of data showed that at the $1^{\text {st }}(250 \mathrm{mg} / 100 \mathrm{ml})$ and the $2^{\text {nd }}(500 \mathrm{mg} / 100 \mathrm{ml})$ MWCNTS concentrations, the total amount of AgNPs was significantly reduced in all MWCNTS exposed samples when compared with the control groups $(\mathrm{P}<0.05)$. Moreover, at the $250 \mathrm{mg} / 100 \mathrm{ml} \mathrm{MWCNTS}$, there were significant differences between $240 \mathrm{~min}$ contact time and the other four contact times (120 min., $60 \mathrm{~min}, 30 \mathrm{~min}$, and $10 \mathrm{~min})(\mathrm{P}<0.05)$ (Table 1). However, there were no significant differences between $120 \mathrm{~min}$., $60 \mathrm{~min}, 30$ min, 10 min and their each other. At the $2^{\text {nd }}$ used MWCNTS concentration (500 $\mathrm{mg} / 100 \mathrm{ml}$ ), the analysis of variance showed significant differences between each $240 \mathrm{~min}, 120 \mathrm{~min}$ and the other 3 contact times $(60 \mathrm{~min}, 30 \mathrm{~min}$, and $10 \mathrm{~min}$ ) (P $<0.05)$. However there were no significant differences between $240 \mathrm{~min}$ and 120 min contact times and also no differences between $60 \mathrm{~min}, 30 \mathrm{~min}, 10 \mathrm{~min}$ and each other (Table 1). These findings indicate that both used concentrations of MWCNTS have efficiency on the removal of AgNPs from aqueous solution. Although many studies have been shown that MWCNTs have been used as adsorbent for many kinds of heavy metals such as zinc ( $\mathrm{Zn}$ ) [28], cadmium (Cd) [29], lead $(\mathrm{Pb})$ [30], nickel $(\mathrm{Ni})$ [31] and copper $(\mathrm{Cu})$ [32], this is the first study showed an effective removal of AgNPs by MWCNTS. The mechanisms by which the metal ions are sorbed onto CNTs are very complicated, however, the most dominant mechanisms reported in the literature are physical adsorption, sorption-precipitation, electrostatic attraction, and chemical interaction between the metal ions and the surface functional groups of CNTs [33] [34] [35]. The surface functional groups and the chemical interaction between CNTs and the metal ions are the most obvious mechanism [36].

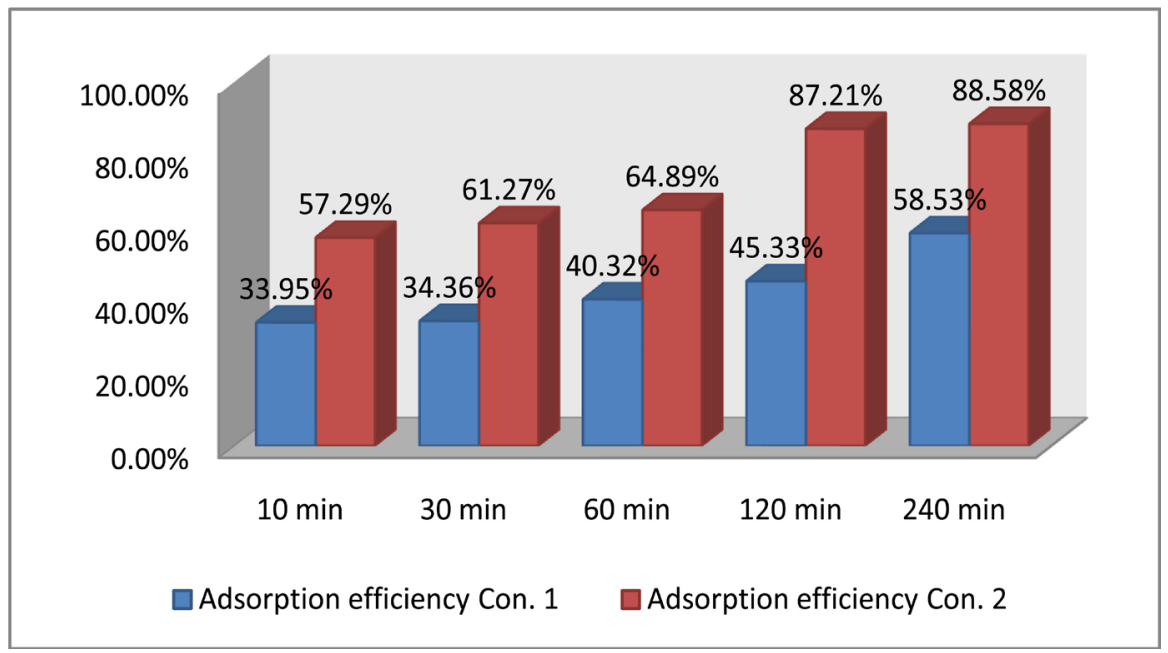

Figure 3. The effect of contact time on the adsorption of AgNPs onto MWCNTS. Con.1 was $250 \mathrm{mg} / 100 \mathrm{ml}$ MWCNTS and Con. 2 was $500 \mathrm{mg} / 100 \mathrm{ml}$ MWCNTS. 
Various researchers have demonstrated that the acid modified CNTs have higher removal efficiency for heavy metals than raw CNTs [33] [35] [37] [38] [39]. However, our results indicate that raw CNTs have good adsorption for AgNPs and that finding agreed with the other group of researchers as [40] [41].

\subsection{Effect of Different Concentration of MWCNTs on Adsorption of AgNPs}

Table 1 showed the effect of 2 concentrations of MWCNTs (250 and 500 $\mathrm{mg} / 100 \mathrm{ml}$ ) on removal efficiency of AgNPs. To compare between the two concentrations, the analysis of variances showed that there were significant differences between each contact time of the second concentration $(500 \mathrm{mg} / 100 \mathrm{ml})$ and the same contact time of first concentration (Table 1). The results also magnified the efficacy of $500 \mathrm{mg} / 100 \mathrm{ml}$ MWCNTS on AgNPs removal, as seen in Table 1 and Figure 3, where the amount of AgNPs remaining in the solution shows a more decreasing trend when comparing by the $1^{\text {st }}$ conc. Our findings showed that there were no significant differences between adsorption of AgNPs at $10 \mathrm{~min}$. onto $500 \mathrm{mg} / 100 \mathrm{ml}$ and the adsorption of AgNPs at $240 \mathrm{~min}$. onto $250 \mathrm{mg} / 100 \mathrm{ml}$ MWCNTS (Table 1). This means that the removal efficiency of AgNPs by $500 \mathrm{mg} / 100 \mathrm{ml}$ MWCNTS for $10 \mathrm{~min}$ (57.29\%) closely similar to the removal efficiency of AgNPs by $250 \mathrm{mg} / 100 \mathrm{ml}$ MWCNTS for $240 \mathrm{~min}$ (58.53\%) (Table 2 and Figure 3). The present data revealed that the removal efficiency of AgNPs increase by increasing the amounts of MWCNTS (Table 1). This result was agreed with [42] who use four synthetic and natural coagulants as attractive option for AgNPs removal at small-scale, the authors observed that the removal percent of AgNPs increases with the increase in coagulant doses, and also in agreement with [43] who used modified MWCNTS for the removal of $\mathrm{Cu}, \mathrm{Pb}$, $\mathrm{Cd}$ and $\mathrm{Zn}$ from aqueous solutions. The present results also agreed with [33] [34] [37] [44] [45] who concluded that, the sorption of heavy metals such as $\mathrm{Ni}^{2+}, \mathrm{Cd}^{2+}, \mathrm{Cu}^{2+}$, and $\mathrm{Pb}^{2+}$ is reported to increase with increase in the CNTs dosage. The increase of adsorption percent of AgNPs with the increase of CNTS dose may be attributed to the fact that, increasing the CNTS dose provided a greater surface area or more adsorption sites for the metal [33] [34] [45] [46].

\subsection{Effect of Contact Times}

Figure 3 and Table 2 showed the effect of different contact times on the adsorption of AgNPs onto MWCNTS. From the present findings, the positive effect of contact time on the AgNPs removal process was achieved by increasing the contact time between MWCNTS and AgNPs. Where, at contact times of 10, 30, 60, 120 and 240 min., the removal of AgNPs reached to 33.95\%, 34.36\%, 40.32\%, $45.33 \%, 58.53 \%$ and $57.29 \%, 61.27 \%, 64.89 \%, 87.21 \%, 88.58 \%$ for 250 and 500 $\mathrm{mg} / 100 \mathrm{ml}$ MWCNTS, respectively Table 2 and Figure 3. Our results showed that the adsorption of AgNPs onto MWCNTS increased quickly with time, and this agreed with the finding of [28] [33] [34] [38] [43]. 
Table 1. Mean \pm Std Error of AgNPs amount before (control) and after adding different concentrations of MWCNTS.

\begin{tabular}{|c|c|c|c|}
\hline \multirow[b]{2}{*}{ Time } & \multirow{2}{*}{ Con. } & \multicolumn{2}{|c|}{ Mean values \pm Std. Error } \\
\hline & & MWCNTS (250 mg/100) & MWCNTS (500 mg/100) \\
\hline $10 \mathrm{~min}$. & & $17.18 \pm 0.41^{\mathrm{b}}$ & $11.11 \pm 0.35^{c}$ \\
\hline $30 \mathrm{~min}$. & & $17.07 \pm 0.67^{\mathrm{b}}$ & $10.07 \pm 0.25^{\mathrm{c}}$ \\
\hline $60 \mathrm{~min}$. & & $15.52 \pm 0.55^{\mathrm{b}}$ & $9.13 \pm 0.55^{c}$ \\
\hline $120 \mathrm{~min}$. & & $14.22 \pm 0.32^{\mathrm{b}}$ & $3.33 \pm 0.31^{\mathrm{d}}$ \\
\hline $240 \mathrm{~min}$. & & $10.78 \pm 0.07^{c}$ & $2.97 \pm 0.02^{\mathrm{d}}$ \\
\hline control & & $26.00 \pm 3.04^{\mathrm{a}}$ & $26.00 \pm 3.04^{\mathrm{a}}$ \\
\hline
\end{tabular}

${ }_{\mathrm{a}, \mathrm{b}, \mathrm{c}, \mathrm{d}, \mathrm{V}}$ alues within columns with no common superscript differ significantly $(\mathrm{P}<0.05)$.

Table 2. The percent removal of AgNPs by MWCNTS after 10, 30, 60, 120, and $240 \mathrm{~min}$.

\begin{tabular}{cccc}
\hline \multirow{2}{*}{ Time } & Con. & \multicolumn{2}{c}{ Adsorption efficiency } \\
\cline { 3 - 4 } & & MWCNTS (250 mg/100) & MWCNTS (500 mg/100) \\
\hline $\mathbf{1 0}$ min. & $33.95 \%$ & $57.29 \%$ \\
$\mathbf{3 0} \mathrm{min}$. & $34.36 \%$ & $61.27 \%$ \\
$\mathbf{6 0} \mathrm{min}$. & $40.32 \%$ & $64.89 \%$ \\
$\mathbf{1 2 0} \mathrm{min}$. & $45.33 \%$ & $87.21 \%$ \\
$240 \mathrm{~min}$. & $58.53 \%$ & $88.58 \%$ \\
\hline
\end{tabular}

\section{Conclusion and Future Research}

From this study, it can be concluded that the MWCNTS possesses a good adsorption performance so that material can be useful in removing nano-sized silver from aqueous solutions. The acceptance of the MWCNTS as an effective adsorbent is expected to remove AgNPs from environment as well as mitigate the toxic effect to both animal and human health. Furthermore, based on the information presented in this study we can make predictions that concentrations of AgNPs may be used in various applications such as water treatment with an increased amount than the permissible limit $(0.1 \mathrm{mg} / \mathrm{l})$, and their removal will be achieved by MWCNTS as additional filtration stage. Finally, further investigations may be needed for MWCNTS exact desorption mechanisms, their possible regeneration, and their application for real aqueous media. The feasibility of CNTs application in large scale treatment also still needs further studies.

\section{Conflict of Interest}

The authors declare that they have no conflict of interest.

\section{References}

[1] Rocío-Bautista, P., et al. (2015) The Metal-Organic Framework HKUST-1 as Efficient Sorbent in a Vortex-Assisted Dispersive Micro Solid-Phase Extraction of Parabens from Environmental Waters, Cosmetic Creams, and Human Urine. Talanta, 
139, 13-20.

[2] Kaegi, R., et al. (2013) Fate and Transformation of Silver Nanoparticles in Urban Wastewater Systems. Water Research, 47, 3866-3877.

[3] Boxall, A., et al. (2012) Pharmaceuticals and Personal Care Products in the Environment: What Are the Big Questions? Environmental Health Perspectives, 120, 1221-1229. https://doi.org/10.1289/ehp.1104477

[4] El-Rafie, M.H., Shaheen, T.I., Mohamed, A.A. and Hebeish, A. (2012) Bio-Synthesis and Applications of Silver Nanoparticles onto Cotton Fabrics. Carbohydrate Polymers, 90, 915-920.

[5] Ribeiro, F., et al. (2014) Silver Nanoparticles and Silver Nitrate Induce High Toxicity to Pseudokirchneriella subcapitata, Daphnia magna and Danio rerio. Science of the Total Environment, 466, 232-241.

[6] Sun, Q., Li, Y., Tang, T., Yuan, Z. and Yu, C.-P. (2013) Removal of Silver Nanoparticles by Coagulation Processes. Journal of Hazardous Materials, 261, 414-420.

[7] Vance, M.E., Kuiken, T., Vejerano, E.P., McGinnis, S.P., Hochella, M.F. and Hull, D.R. (2015) Nanotechnology in the Real World: Redeveloping the Nanomaterial Consumer Products Inventory. Beilstein Journal of Nanotechnology, 6, 1769-1780. https://doi.org/10.3762/bjnano.6.181

[8] Blaser, S.A., Scheringer, M., MacLeod, M. and Hungerbühler, K. (2008) Estimation of Cumulative Aquatic Exposure and Risk Due to Silver: Contribution of NanoFunctionalized Plastics and Textiles. Science of the Total Environment, 390, 396409.

[9] Gottschalk, F., Sonderer, T., Scholz, R.W. and Nowack, B. (2009) Modeled Environmental Concentrations of Engineered Nanomaterials $\left(\mathrm{TiO}_{2}, \mathrm{ZnO}, \mathrm{Ag}, \mathrm{CNT}\right.$, Fullerenes) for Different Regions. Environmental Science \& Technology, 43, 92169222. https://doi.org/10.1021/es9015553

[10] Limbach, L.K., Bereiter, R., Muller, E., Krebs, R., Galli, R. and Stark, W.J. (2008) Removal of Oxide Nanoparticles in a Model Wastewater Treatment Plant: Influence of Agglomeration and Surfactants on Clearing Efficiency. Environmental Science \& Technology, 42, 5828-5833. https://doi.org/10.1021/es800091f

[11] Dosoky, R., Kotb, S. and Farghali, M. (2015) Efficiency of Silver Nanoparticles against Microbial Contaminants Isolated from Surface and Ground Water in Egypt. Journal of Advanced Veterinary and Animal Research, 2, 175-184. https://doi.org/10.5455/javar.2015.b79

[12] Bielmyer, G.K., Bell, R.A. and Klaine, S.J. (2002) Effects of Ligand-Bound Silver on Ceriodaphnia dubia. Environmental Toxicology and Chemistry, 21, 2204-2208. https://doi.org/10.1002/etc.5620211026

[13] He, D., Dorantes-Aranda, J.J. and Waite, T.D. (2012) Silver Nanoparticle-Algae Interactions: Oxidative Dissolution, Reactive Oxygen Species Generation and Synergistic Toxic Effects. Environmental Science \& Technology, 46, 8731-8738. https://doi.org/10.1021/es300588a

[14] Lee, W.-M., Il Kwak, J. and An, Y.-J. (2012) Effect of Silver Nanoparticles in Crop Plants Phaseolus radiatus and Sorghum bicolor. Media Effect on Phytotoxicity. Chemosphere, 86, 491-499.

[15] Chambers, B.A., et al. (2013) Effects of Chloride and Ionic Strength on Physical Morphology, Dissolution, and Bacterial Toxicity of Silver Nanoparticles. Environmental Science \& Technology, 48, 761-769. https://doi.org/10.1021/es403969x

[16] Lowry, G.V., Gregory, K.B., Apte, S.C. and Lead, J.R. (2012) Transformations of Nanomaterials in the Environment. Environmental Science \& Technology, 46, 
6893-6899. https://doi.org/10.1021/es300839e

[17] Pulit-Prociak, J. and Banach, M. (2016) Silver Nanoparticles-A Material of the Future...? Open Chemistry, 14, 76-91. https://doi.org/10.1515/chem-2016-0005

[18] Hadrup, N. and Lam, H.R. (2014) Oral Toxicity of Silver Ions, Silver Nanoparticles and Colloidal Silver-A Review. Regulatory Toxicology and Pharmacology, 68, 1-7.

[19] Iijima, S. (1991) Helical Microtubules of Graphitic Carbon. Nature, 354, 56-58. https://doi.org/10.1038/354056a0

[20] Dai, H. (2002) Carbon Nanotubes: Opportunities and Challenges. Surface Science, 500, 218-241.

[21] Wang, Y., Wei, F., Luo, G., Yu, H. and Gu, G. (2002) The Large-Scale Production of Carbon Nanotubes in a Nano-Agglomerate Fluidized-Bed Reactor. Chemical Physics Letters, 364, 568-572.

[22] Mubarak, N.M., Sahu, J.N., Abdullah, E.C. and Jayakumar, N.S. (2014) Removal of Heavy Metals from Wastewater Using Carbon Nanotubes. Separation \& Purification Reviews, 43, 311-338. https://doi.org/10.1080/15422119.2013.821996

[23] El-Sheikh, A.H., Insisi, A.A. and Sweileh, J.A. (2007) Effect of Oxidation and Dimensions of Multi-Walled Carbon Nanotubes on Solid Phase Extraction and Enrichment of Some Pesticides from Environmental Waters Prior to Their Simultaneous Determination by High Performance Liquid Chromatography. Journal of Chromatography A, 1164, 25-32.

[24] Fang, G.-Z., He, J.-X. and Wang, S. (2006) Multiwalled Carbon Nanotubes as Sorbent for On-Line Coupling of Solid-Phase Extraction to High-Performance Liquid Chromatography for Simultaneous Determination of 10 Sulfonamides in Eggs and Pork. Journal of Chromatography A, 1127, 12-17.

[25] Dehghani, M.H., et al. (2016) Optimizing the Removal of Organophosphorus Pesticide Malathion from Water Using Multi-Walled Carbon Nanotubes. Chemical Engineering Journal, 310, 22-32.

[26] Long, R.Q. and Yang, R.T. (2001) Carbon Nanotubes as Superior Sorbent for Dioxin Removal. Journal of the American Chemical Society, 123, 2058-2059. https://doi.org/10.1021/ja0038301

[27] Vigneshwaran, N., Nachane, R.P., Balasubramanya, R.H. and Varadarajan, P.V. (2006) A Novel One-Pot "Green" Synthesis of Stable Silver Nanoparticles Using Soluble Starch. Carbohydrate Research, 341, 2012-2018.

[28] Lu, C. and Chiu, H. (2006) Adsorption of Zinc (II) from Water with Purified Carbon Nanotubes. Chemical Engineering Science, 61, 1138-1145.

[29] Vuković, G.D., et al. (2010) Removal of Cadmium from Aqueous Solutions by Oxidized and Ethylenediamine-Functionalized Multi-Walled Carbon Nanotubes. Chemical Engineering Journal, 157, 238-248.

[30] Li, Y.-H., Zhu, Y., Zhao, Y., Wu, D. and Luan, Z. (2006) Different Morphologies of Carbon Nanotubes Effect on the Lead Removal from Aqueous Solution. Diamond and Related Materials, 15, 90-94.

[31] Kandah, M.I. and Meunier, J.-L. (2007) Removal of Nickel Ions from Water by Multi-Walled Carbon Nanotubes. Journal of Hazardous Materials, 146, 283-288.

[32] Li, Y.-H., et al. (2003) Removal of $\mathrm{Cu}^{2+}$ Ions from Aqueous Solutions by Carbon Nanotubes. Adsorption Science \& Technology, 21, 475-485. https://doi.org/10.1260/026361703769645807

[33] Gupta, V.K., et al. (2016) Study on the Removal of Heavy Metal Ions from Industry Waste by Carbon Nanotubes: Effect of the Surface Modification: A Review. Critical Reviews in Environmental Science and Technology, 46, 93-118. 
https://doi.org/10.1080/10643389.2015.1061874

[34] Rao, G.P., Lu, C. and Su, F. (2007) Sorption of Divalent Metal Ions from Aqueous Solution by Carbon Nanotubes: A Review. Separation and Purification Technology, 58, 224-231.

[35] Ren, X., Chen, C., Nagatsu, M. and Wang, X. (2011) Carbon Nanotubes as Adsorbents in Environmental Pollution Management: A Review. Chemical Engineering Journal, 170, 395-410.

[36] Lu, C. and Liu, C. (2006) Removal of Nickel(II) from Aqueous Solution by Carbon Nanotubes. Journal of Chemical Technology and Biotechnology, 81, 1932-1940. https://doi.org/10.1002/jctb.1626

[37] Al-Khaldi, F.A., et al. (2015) Adsorptive Removal of Cadmium (II) Ions from Liquid Phase Using Acid Modified Carbon-Based Adsorbents. Journal of Molecular Liquids, 204, 255-263.

[38] Fu, F. and Wang, Q. (2011) Removal of Heavy Metal Ions from Wastewaters: A Review. Journal of Environmental Management, 92, 407-418.

[39] Ihsanullah, et al. (2016) Effect of Acid Modification on Adsorption of Hexavalent Chromium (Cr(VI)) from Aqueous Solution by Activated Carbon and Carbon Nanotubes. Desalination and Water Treatment, 57, 7232-7244. https://doi.org/10.1080/19443994.2015.1021847

[40] Pillay, K., Cukrowska, E.M. and Coville, N.J. (2009) Multi-Walled Carbon Nanotubes as Adsorbents for the Removal of Parts per Billion Levels of Hexavalent Chromium from Aqueous Solution. Journal of Hazardous Materials, 166, 1067 1075.

[41] Wang, H., Zhou, A., Peng, F., Yu, H. and Yang, J. (2007) Mechanism Study on Adsorption of Acidified Multiwalled Carbon Nanotubes to $\mathrm{Pb}(\mathrm{II})$. Journal of Colloid and Interface Science, 316, 277-283.

[42] Ahmed, T., et al. (2016) A Comparative Study of Synthetic and Natural Coagulants for Silver Nanoparticles Removal from Wastewater. Desalination and Water Treatment, 57, 18718-18723. https://doi.org/10.1080/19443994.2015.1093554

[43] Kosa, S.A., Al-Zhrani, G. and Abdel Salam, M. (2012) Removal of Heavy Metals from Aqueous Solutions by Multi-Walled Carbon Nanotubes Modified with 8-Hydroxyquinoline. Chemical Engineering Journal, 181-182, 159-168.

[44] Li, Y.-H., et al. (2003) Competitive Adsorption of $\mathrm{Pb}^{2+}, \mathrm{Cu}^{2+}$ and $\mathrm{Cd}^{2+}$ Ions from Aqueous Solutions by Multiwalled Carbon Nanotubes. Carbon, 41, 2787-2792.

[45] Li, Y.-H., Wang, S., Luan, Z., Ding, J., Xu, C. and Wu, D. (2003) Adsorption of Cadmium (II) from Aqueous Solution by Surface Oxidized Carbon Nanotubes. Carbon, 41, 1057-1062.

[46] Rengaraj, S. and Moon, S.-H. (2002) Kinetics of Adsorption of Co(II) Removal from Water and Wastewater by Ion Exchange Resins. Water Research, 36, 1783-1793. 


\section{期刊投稿者将享受如下服务:}

1. 投稿前咨询服务 (QQ、微信、邮箱皆可)

2. 为您匹配最合适的期刊

3. 24 小时以内解答您的所有疑问

4. 友好的在线投稿界面

5. 专业的同行评审

6. 知网检索

7. 全网络覆盖式推广您的研究

投稿请点击： http://www.hanspub.org/Submission.aspx

期刊邮箱: anp@hanspub.org 